\title{
Social Dynamics in the Russian Far East: Failure of the Institutional Paradigm
}

\author{
P. A. Minakir ${ }^{a, *}$ and S. N. Naiden ${ }^{a, * *}$ \\ ${ }^{a}$ Economic Research Institute, Far Eastern Branch, Russian Academy of Sciences, Khabarovsk, 680042 Russia \\ *e-mail:minakir@ecrin.ru \\ **e-mail: naidensvetlana@mail.ru
}

Received May 27, 2020; revised May 28, 2020; accepted January 23, 2021

\begin{abstract}
Measures to curb population outflow and increase human capital, including by ensuring attractive conditions and high living standards and quality of life, are declared the most important priority for development of the Russian Far East and implementation of state policy in the macroregion. Despite the creation of additional institutional incentives, the adoption of special programs at the state level and joining of two subjects to the Far Eastern Federal District in 2018, the parameters of sociodemographic dynamics in the macroregion remain lower than expected. Based on an analysis of indicators of natural population movement and migration, household income and expenditures, quality of life in all 11 federal subjects of the Far Eastern Federal District, trends, and achieved results of "indirect institutional incentives" are demonstrated. The authors conclude that after 30 years of reforms aimed at improving the level and quality of life of the population in Russia and creating comfortable living conditions in the Far East, the factors hindering these processes remain unchanged. Consequently, failures in stabilizing the demographic potential and developing the social system in the Far East are mainly due to incorrect emphasis of state policy on "institutional regulation" in this area, i.e., failure of the institutional paradigm to achieve the policy goal.
\end{abstract}

Keywords: demography, migration, household income and expenditures, poverty, quality of life, Far East DOI: $10.1134 /$ S2079970521020118

\section{INTRODUCTION}

For more than 150 years, the general idea of development of the Russian Far East remains on the agenda. This idea, of course, underwent significant modification: from the tactics of colonizing new territorial acquisitions of the empire, through the creation of a military-political outpost on the Pacific Ocean, to the formation of a rapidly developing enclave integrated into the subglobal economic system. Studies and descriptions of these historical stages and the content of the corresponding turns of national economic and social policy are reflected in the extensive scientific literature (Aganbegyan, 2019; Minakir, 2017a; Rossiiskii..., 2017; Tikhookeanskaya..., 2010; Tikhookeanskaya..., 2011), dedicated to economic, social, political, and even technological aspects of regional development. As an object of state economic policy, the Far East has repeatedly undergone changes (see (Minakir, 2006, pp. 135-140, 157-158), as well as the Decree of the President of the Russian Federation of November $3,2018^{1}$ ), but the policy basis for the forma-

\footnotetext{
${ }^{1}$ Decree of the President of the Russian Federation of November 3, 2018 no. 632 On Amendments to the List of Federal Districts Approved by the Decree of the President of the Russian Federation of May 13, 2000 no. 849. https://www.garant.ru/products/ipo/prime/doc/71996370/.
}

tion and implementation of state policy remained unchanged.

Since the first state program for development of the Far East (1987), ${ }^{2}$ attracting and consolidating the population has traditionally been declared the most important priority of state policy for this region. By 2000 , it was planned to increase the regional population $^{3}$ up to $9.2 \mathrm{mln}$ people, including $8.2 \mathrm{mln}$ people by 1991 . These expectations were based on real industrial and infrastructure projects in the region, as well as programs for its social development (Minakir, 2006, p. 341). In 1990, expectations were almost met: the population was $8.08 \mathrm{mln}$, but already in 1991 the average annual population growth rate of $1.4 \%$ for $1981-$

\footnotetext{
2 The long-term state program for integrated development of productive forces of the Far Eastern economic region, Buryat ASSR, and Chita Oblast for the period up to 2000: Approved by Resolution of the Central Committee of the CPSU and Council of Ministers of the USSR no. 958 dated August 19, 1987 On the Integrated Development of the Productive Forces of the Far Eastern Economic Region, Buryat ASSR and Chita Oblast for the period up to $2000 / /$ Library of normative legal acts of the USSR. http://www.libussr.ru/doc_ussr/usr_14218.htm.

${ }^{3}$ By region, we mean the Far Eastern Economic Area, comprising Primorsky and Khabarovsk krais, Yakut ASSR, and Amur, Kamchatka, Magadan, and Sakhalin oblasts.
} 


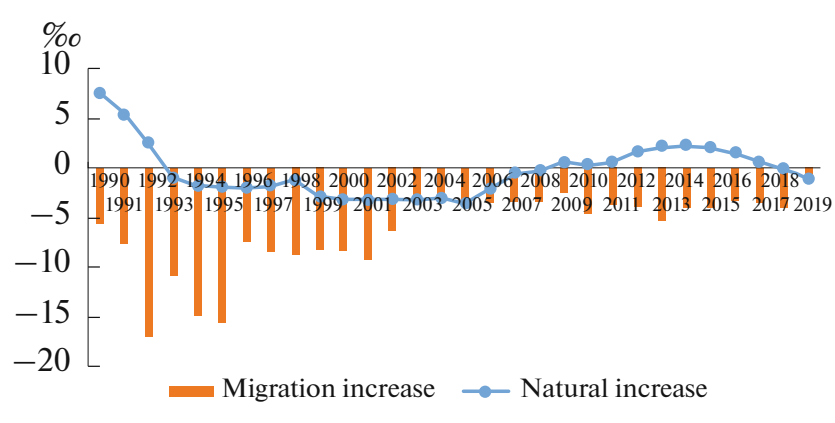

Fig. 1. Population increase rates of the FEFD (per 1000 people).

1990 was replaced by a decrease in inhabitants by $0.3 \%$; the entire decrease was due to migration (Minakir, 2006, pp. 341-342).

\section{POPULATION DYNAMICS}

The transition to "shock therapy" was accompanied by political collapse of the country, destruction of the production structure, and severing of technological and logistic ties. It dramatically changed the population trend in the Far East. Migration began to lose importance as a factor in population growth. Whereas before 1960, migration was responsible for about $50 \%$ of the increase in inhabitants, and in 1961-1985, about $30 \%$, in 1986-1990 this share dropped to $17 \%$, and in 1989-1990, net migration became completely negative (the decrease in the regional population amounted to 11300 people in these years). In 1991, the population outflow exceeded its natural increase for the first time (Minakir, 2006, pp. 616-617). A long period of decrease in inhabitants in the region began (Fig. 1), both due to migration and a negative natural increase.

As has been repeatedly noted in the scientific literature (Minakir, 2017b), migration losses stemmed from a number of objective trends, which in aggregate triggered a shock in the employment market (an almost immediate reduction in demand for labor) and a corresponding decrease in the price of labor in the region. This contributed to the rapid loss of competitiveness in the Far East in terms of revenues, which previously compensated for the relatively low level of living comfort in the region compared to other regions of the country. Another, and in many ways most important, reason for the rapid change in positive to negative net migration was the collapse of a fundamental social institution from aspect of the settlement pattern in the Far East: those who migrated to the Far East were guaranteed retention of the right to housing in their "home" regions. The destruction of this institution, as well as the actual elimination of a second fundamental institution-guarantees for accumulated savings by migrants, ensuring a comfortable future "post-Eastern" life-predetermined the region's drop in population to approximately the mid-1970s level (Minakir, 2017b). ${ }^{4}$

Addendum of the Republic of Buryatia and Zabaykalsky Krai to the Far Eastern Federal District (FEFD) in 2018 (relatively favorable in terms of demographic dynamics) improved the dynamics that had developed in 2009-2017. Positive and relatively high values of the natural population growth rate in these territories, together with high values in the Sakha Republic (Yakutia) and Chukotka Autonomous Okrug (Table 1), formed a small crest of the natural population growth curve for the Far East as a whole (see Fig. 1).

However, the traditionally high birth rate among the indigenous population in the Sakha Republic (Yakutia), the Republic of Buryatia, Kamchatka Krai, the Chukotka Autonomous Okrug, Zabaykalsky Krai has improved the statistical pattern of natural population growth in the Far East compared to the Russian Federation as a whole. However, the overall negative situation in the region has not been overcome, since the southern (most populated) zone shows a monotonic natural decrease. Even the positive (or neutral) dynamics of natural population movement in 20122017 in Khabarovsk Krai and Magadan and Sakhalin oblasts was unable to change the general stable negative trend versus the deteriorating age structure of the population, although a more populous generation came of reproductive age, and its reproductive behavior was supported by the effect of maternity capital and other institutional innovations (Motrich, 2019, p. 33; Motrich and Molodkovets, 2019). Since 2018, in the region as a whole, mortality has again begun to exceed the birth rate (by 402 people in 2018 and by 8957 people in 2019). This gives grounds to assume the presence of a stable negative trend in the natural population movement: the general indicators of natural population growth in the FEFD have returned to the negative zone since 2018. Of course, the extremely negative results of the COVID-19 pandemic in the first half of 2020 will also be added to the natural factors in the long term.

In contrast to natural movement of the regional population, its migration throughout the post-Soviet period had a strictly unambiguous trend (Rybakovsky and Kozhevnikova, 2015). The migration increase was constantly negative (see Fig. 1). The smallest negative migration increase was recorded in 2019 due to positive values in the Chukotka Autonomous Okrug and zero values in Primorsky Krai and Amur Oblast. These exceptions were associated with the creation of new jobs in these territories, which attracted a significant contingent of labor resources on a rotational and permanent basis (Table 2). However, the general negative migration trend for the region as a whole persisted. The most intensive migration exchange remains in the

\footnotetext{
${ }^{4}$ Data on the regional population since the beginning of the 20th century (see (Motrich and Naiden, 2009, p. 48)).
} 
Table 1. Natural population increase rates in FEFD federal subjects, per 1000 people

\begin{tabular}{l|r|r|r|r|r}
\hline \multicolumn{1}{c|}{ Federal subject } & 2010 & 2015 & 2017 & 2018 & 2019 \\
\hline Republic of Buryatia & 4.3 & 5.9 & 3.8 & 3.4 & 1.6 \\
Sakha Republic (Yakutia) & 7.0 & 8.6 & 6.4 & 5.9 & 5.4 \\
Zabaykalsky Krai & 2.1 & 2.5 & 1.7 & 0.4 & -0.6 \\
Kamchatka Krai & -0.6 & 1.6 & 0.9 & -0.5 & -0.5 \\
Primorsky Krai & -2.5 & -0.8 & -2.4 & -2.9 & -3.9 \\
Khabarovsk Krai & -1.7 & 0.9 & -1.0 & -1.4 & -2.4 \\
Amur Oblast & -1.5 & -0.6 & -1.6 & -2.3 & -4.0 \\
Magadan Oblast & -1.5 & 0.0 & -0.5 & -1.4 & -2.2 \\
Sakhalin Oblast & -2.8 & 0.4 & 1.0 & -0.5 & -0.8 \\
Jewish Autonomous & -1.9 & -1.4 & -1.6 & -2.0 & -3.7 \\
Oblast & & & & & \\
Chukotka Autonomous & 0.9 & 4.1 & 3.7 & 1.6 & 1.4 \\
Okrug & $\mathbf{0 . 3}$ & $\mathbf{2 . 0}$ & $\mathbf{0 . 6}$ & $\mathbf{- 0 . 1}$ & $\mathbf{- 1 . 1}$ \\
FEFD & $\mathbf{- 1 . 7}$ & $\mathbf{0 . 3}$ & $\mathbf{- 0 . 9}$ & $\mathbf{- 1 . 6}$ & $\mathbf{- 2 . 2}$ \\
Russia
\end{tabular}

Source: Regions of Russia: Socioeconomic indicators: Stat. Dig., Moscow: Rosstat, 2010-2019; Socioeconomic position of FEFD in 2019: Stat. bull., Moscow: Rosstat, 2019. P. 49.

Far Eastern federal subjects, the development of which to a greater extent occurs on a rotational basis. It is difficult to say how many of those who left the Far East departed after the end of their temporary employment, but it can be unequivocally stated that in addition to them, outflow of the permanent population continues. The decrease in negative net migration in 2019 (to -11700 people compared to -33100 people in 2018) cannot yet be regarded as anything other than an episode.
The cumulative impact of trends in natural movement and population migration has led to a demographic shock that has lasted for almost 30 years. The regional population for 1991-2020 decreased by $2.26 \mathrm{mln}$ people $(21.7 \%)$, if we mean the "extended region" within the boundaries of 2018, and by 1.94 mln people. (25.1\%) for the 1991-2017 borders. The population declined in all Far Eastern regions. The greatest relative losses were suffered by federal subjects of the northeastern zone: Chukotka Autonomous Okrug, Magadan and Sakhalin oblasts, and Kamchatka Krai. The single-industry specialization of their economies hindered the emergence of structural alternatives for the employment market, and the social infrastructure and quality of life in these territories were deliberately uncompetitive from the aspect of migrants, who formed the bulk of the population in these territories, compared to the places of departure for these migrants. Of course, the most severe population losses in absolute terms (almost $47 \%$ of the total population decrease) were suffered by four regions of the southern zone (Primorsky and Khabarovsk krais, Amur Oblast, and the Jewish Autonomous Oblast). Although their economies were relatively more diversified, it was in these territories that the largest decline in employment in labor-intensive manufacturing industries experienced the largest structural shock to demand since 1991 (Table 3).

In 2002, in a speech by the President of the Russian Federation in Blagoveshchensk (Amur Oblast), a return of the state to a preferential policy in the Far East was declared. The "presidential program" for the development of the region adopted back in 1996 was even corrected, which in turn was a 1987 program updated for the new conditions. Strengthening of the

Table 2. Migration increase rates in FEFD federal subjects, per 10000 people

\begin{tabular}{l|c|c|c|c|r|r}
\hline \multicolumn{1}{c|}{ Federal subject } & 2005 & 2010 & 2015 & 2017 & 2018 & 2019 \\
\hline Republic of Buryatia & -26 & -24 & -20 & -35 & -47 & 10 \\
Sakha Republic (Yakutia) & -28 & -71 & -56 & -48 & -31 & -3 \\
Zabaykalsky Krai & -47 & -46 & -66 & -74 & -69 & -52 \\
Kamchatka Krai & -199 & -41 & -53 & 17 & -22 & -51 \\
Primorsky Krai & -51 & -35 & -14 & -29 & -24 & 0 \\
Khabarovsk Krai & -93 & -31 & -37 & -28 & -37 & -23 \\
Amur Oblast & -100 & -60 & -47 & -26 & -43 & 0 \\
Magadan Oblast & -180 & -141 & -118 & -97 & -187 & -53 \\
Sakhalin Oblast & -104 & -63 & -27 & 49 & -7 & -22 \\
Jewish Autonomous Oblast & -159 & -49 & -120 & -119 & -111 & -65 \\
Chukotka Autonomous Okrug & 73 & -174 & -117 & -132 & 48 & 109 \\
FEFD & $-\mathbf{3 3}$ & $\mathbf{- 4 6}$ & $-\mathbf{4 0}$ & $-\mathbf{3 5}$ & $\mathbf{- 4 0}$ & $\mathbf{- 1 4}$ \\
Russia & $\mathbf{2 0}$ & $\mathbf{1 9}$ & $\mathbf{1 7}$ & $\mathbf{1 4}$ & $\mathbf{9}$ & $\mathbf{1 9}$ \\
\hline
\end{tabular}

Source: Regions of Russia: Socioeconomic indicators: Stat. Dig., Moscow: Rosstat, 2010-2019; Socioeconomic position of the FEFD in 2019: Stat. bull., Moscow: Rosstat, 2019. P. 50. 
Table 3. Size and dynamics of FEFD federal subjects' population

\begin{tabular}{|c|c|c|c|c|c|c|}
\hline \multirow{2}{*}{ Federal subject } & \multicolumn{3}{|c|}{ Population, thous. people } & \multicolumn{3}{|c|}{ Increase/decrease, $\%$} \\
\hline & 1991 & 2015 & 2020 & $1991-2020$ & $19911-2015$ & $2015-2020$ \\
\hline Republic of Buryatia & 1052.0 & 980.4 & 985.9 & -6.3 & -6.8 & +0.6 \\
\hline Sakha Republic (Yakutia) & 1119.0 & 958.3 & 972.0 & -13.1 & -14.4 & +1.4 \\
\hline Zabaykalsky Krai & 1317.9 & 1085.2 & 1059.7 & -19.6 & -17.7 & -2.4 \\
\hline Kamchatka Krai & 478.5 & 316.7 & 313.0 & -34.6 & -33.8 & -1.2 \\
\hline Primorsky Krai & 2309.7 & 1931.2 & 1895.9 & -17.9 & -16.4 & -1.8 \\
\hline Khabarovsk Krai & 1624.7 & 1336.4 & 1315.6 & -19.0 & -17.8 & -1.6 \\
\hline Amur Oblast & 1054.3 & 807.8 & 790.0 & -25.1 & -23.4 & -2.2 \\
\hline Magadan Oblast & 384.5 & 147.2 & 140.1 & -63.6 & -61.7 & -4.8 \\
\hline Sakhalin Oblast & 715.3 & 487.8 & 488.3 & -31.7 & -31.8 & +0.1 \\
\hline Jewish Autonomous Oblast & 219.3 & 167.2 & 158.3 & -27.8 & -23.8 & -5.3 \\
\hline Chukotka Autonomous Okrug & 158.1 & 50.2 & 50.3 & -68.2 & -68.3 & +0.2 \\
\hline FEFD & 10433.3 & 8268.6 & 8169.2 & -21.7 & -20.8 & -1.2 \\
\hline
\end{tabular}

Data as of January 1 of the corresponding year.

population and social development were mentioned as one of the goals in the 2002 program. ${ }^{5}$ However, even this version of the program did not introduce any changes in the general demographic trend. Until 2015, the intensive population outflow continued. New hopes were inspired by an avalanche of institutional innovations (introduction of a regime of priority development areas, free distribution of land, introduction of the free port of Vladivostok, averaging energy tariffs for Far Eastern producers, introduction of preferential prices for air passengers, etc.) (Rossiiskii..., 2017), which has descended on the Far East since 2015.

True, to date, the promised changes in the migration and demographic situation have not occurred, although within a large-scale propaganda campaign, optimistic reports have repeatedly mentioned successes based on radical improvement in the quality of life as a result of increased investment, improvement in the business climate, and increased tempo of restructuring of the economy. Integration with the Asia-Pacific Region has not occurred either. However, the intensity of the negative population dynamics

\footnotetext{
${ }^{5}$ Federal target program "Economic and Social Development of the Far East and Transbaikalia for 1996-2005 and until 2010:" Approved by Resolution of the Government of the Russian Federation no. 480 dated April 15, 1996 (as amended by Resolution of the Government of the Russian Federation dated March 19, 2002 no. 169). http://www.nsc.ru/win/sbras/bef/pos480.html.
}

has significantly decreased (see Table 3 ) due to the above-mentioned change in net migration in resource regions, Primorsky Krai, and Amur Oblast, where investors have directed significant financial resources, which has caused a concomitant flow of labor resources. Attraction of investments is partly connected with new benefits, partly with support of public resources, and partly with the pressure of "soft power" in the form of a political imperative.

However, so far we cannot talk about a change in the type of endogenous demographic dynamics, a change in the behavior strategy of indigenous people and migrants, or fundamental motivational shifts. Permanent residents continue to leave: clearly something does not suit those who, having arrived to work, could potentially stay for a longer period, but at the end of their contract decide to leave the region. Part of the answer is found in the comparative practice of stimulating attraction of the population to the region and keeping it there.

\section{HOUSEHOLD INCOMES}

During the Soviet period, the policy of attracting people to the Far East and consolidating it in this region relied on a decrease in the level of alternative incomes for those who would go and live there. The guaranteed wages were 1.5-2 times higher than the national average (Minakir, 2006). Owing to public investment, specific life support systems were created 


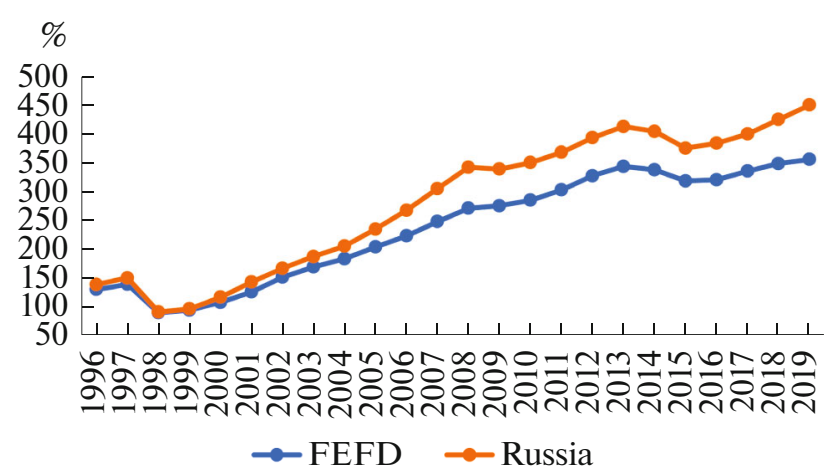

Fig. 2. Real wages index, $\%(1995=100)$.

that could function smoothly in an autonomous mode in a harsh climate, social infrastructure facilities were erected to provide the minimum necessary needs for socially significant services (housing, education, health care, culture and sports). Quite naturally, spatial differences in the economic conditions in which enterprises and sectors functioned continued in the differentiated living conditions in cities and towns scattered over the vast macroregion. Nevertheless, the modest demand of the Far East for social services with their narrow range and low quality, including a permanent housing shortage, was due to how residence was viewed as temporary, the duration of which, as a rule, did not exceed the period of employment.

Since the 1990s, this fundamental principle has been consigned to oblivion. The alternative income level for the Far East has sharply increased: in 19952019, nominal wages in the economy of the FEFD increased 70 times, while on average in Russia, it was 100 times. Whereas in the mid-1990s, the wages of Far Easterners at face value (due to the corresponding allowances and coefficients compensating for the distance and harsh natural and climatic conditions) exceeded the average Russian level by $71 \%$, by now this advantage has decreased to only $18 \%$. At the same time, the lag in the growth rate of real wages in the Far East behind the average Russian rates has been increasing since 2000 , despite significant improvement in the general economic situation and declaration of a turn in state policy towards the Far East (Fig. 2).

On the whole, this testifies to slippage of regional policy as an institution. This is due to a host of circumstances, including the unified, average statistical approach to analyzing the situation and development of response measures that prevailed in the post-Soviet period. In particular, in the Far East, wages are significantly more important in the formation of real household incomes. On average in the Russian Federation, the share of wages in total household income in 2019 was $58 \%,{ }^{6}$ and in the Far East, $65-70 \%$ in the southern zone and up to $75-80 \%$ in the northern (Fig. 3).
The opportunities for obtaining high wages and other incomes in these regions are limited, and the level of wages in the most massive sectors in terms of the number of employees (education, health care, culture) is much lower than in the extractive or financial sectors of the regional economy. This creates significant differences in the possibilities of forming high household incomes. In addition to this is the significantly smaller role in the formation of income from business activities and rent from property, including interest on deposits, securities, and investment income. ${ }^{7}$ With the relatively weak entrepreneurial sector in the Far East region, the rate of its leaching-out significantly exceeds the rate of liquidation of enterprises and organizations in other regions of the country. In 2018, 155 units were liquidated per thousand enterprises and organizations in the FEFD, while on average in the Russian Federation, there were only 110; in the Far East, small and medium-sized businesses are generally very mediocre (Aganbegyan, 2019, pp. 169-170). The importance of social transfers, accounting for $19-21 \%$ of all income, is most significant in traditionally subsidized regions: the Jewish Autonomous Oblast, Zabaykalsky Krai, Republic of Buryatia, Sakha Republic (Yakutia), Kamchatka Krai, and Amur Oblast.

As a result, the excess level of per capita real household incomes in the Far East over the average Russian level decreased from about 26\% in 1995 (associated with high nominal incomes in Far North regions) to $7 \%$ in 2019. In the East, the level of real incomes is even lower than the national average (in Amur Oblast, 93\%; in the Jewish Autonomous Oblast, Republic of Buryatia, and Zabaykalsky Krai, 70-75\%).

The fact that the income distribution in the Far East is even greater than the Russian average is a very small consolation. Indeed, the Gini coefficient for federal subjects in the Far East today varies from 0.349 to 0.405 , with the average value for Russia of 0.413 . An exception is Sakhalin Oblast, where this coefficient is 0.418 . "Greater equity" in the income distribution is actually indicative of the limited nature of activities that generate higher incomes, as well as the aforementioned prevalence of wage labor. The higher Gini coefficient in the Far East (0.405-0.418) is characteristic of federal subjects in which extractive industries with higher wages are concentrated (the Sakha Republic (Yakutia), Sakhalin Oblast, the Chukotka Autonomous Okrug). ${ }^{8}$

\footnotetext{
${ }^{6}$ Volume and structure of real household incomes in the Russian Federation by sources of income. https://www.gks.ru/ folder/13397? print $=1$.

${ }^{7}$ Monthly monitoring of the socioeconomic situation and wellbeing of the population: 2015-November 2018, Maleva, T.M., Ed., Moscow: Ros. akad. nar. khoz-va i gos. sluzhby pri Prezidente Rossiiskoi Federatsii, 2018, P. 30. https://www.ranepa.ru/ images/News/2018-12/19-12-2018-monitoring.pdf.

${ }^{8}$ Regions of Russia: Socioeconomic indicators. 2019: Stat. Dig., Moscow: Rosstat, 2019. https://gks.ru/bgd/regl/b19_14p/ Main.htm.
} 


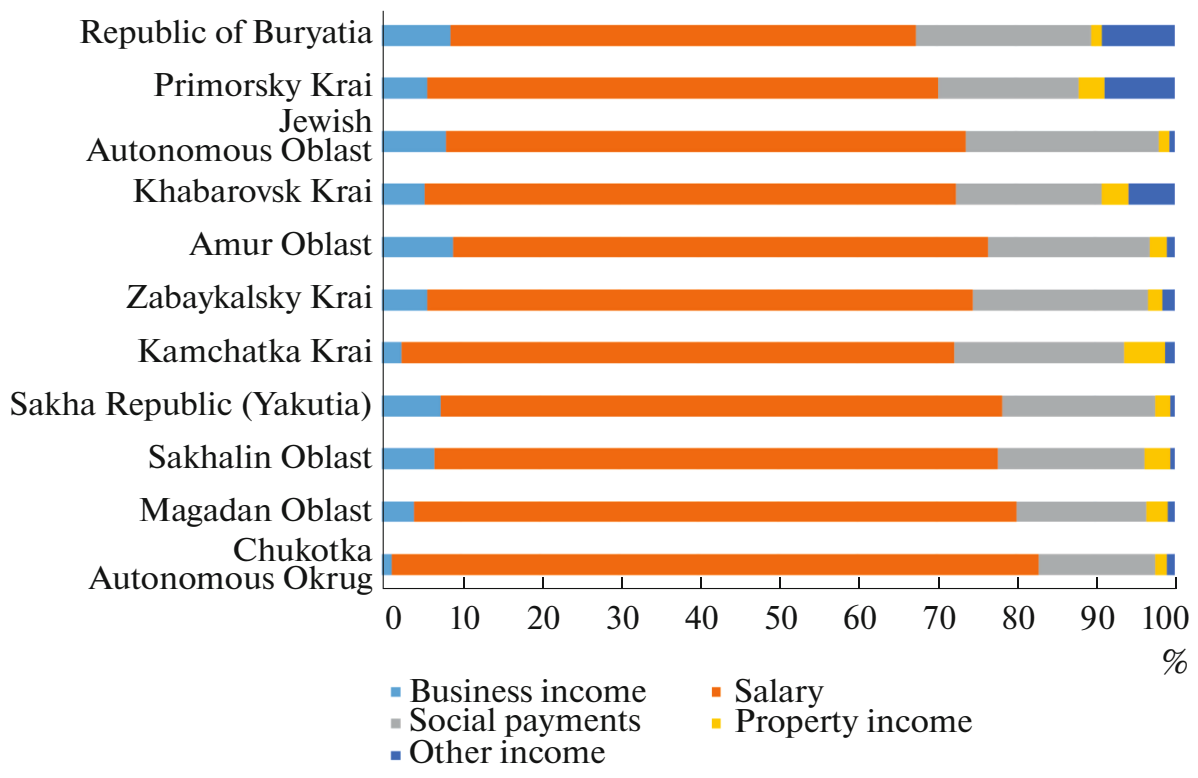

Fig. 3. Structure of money income in regions of FEFD, $\%$.

With a constantly decreasing relative household income level, the cost of the fixed set of consumer goods and services in the Far East is significantly higher than the average for Russia (Fig. 4). In Kamchatka Krai and Sakhalin and Magadan oblasts, this excess is 40-60\%; in Khabarovsk and Primorsky krais, 25-30\%; and in the Chukotka Autonomous Okrug, 80-100\%. Far Easterners' costs for utility bills and housing maintenance are also relatively higher. Whereas the average cost for these in Russia as a whole is $9.6 \%$ of the total amount of consumer spending, in

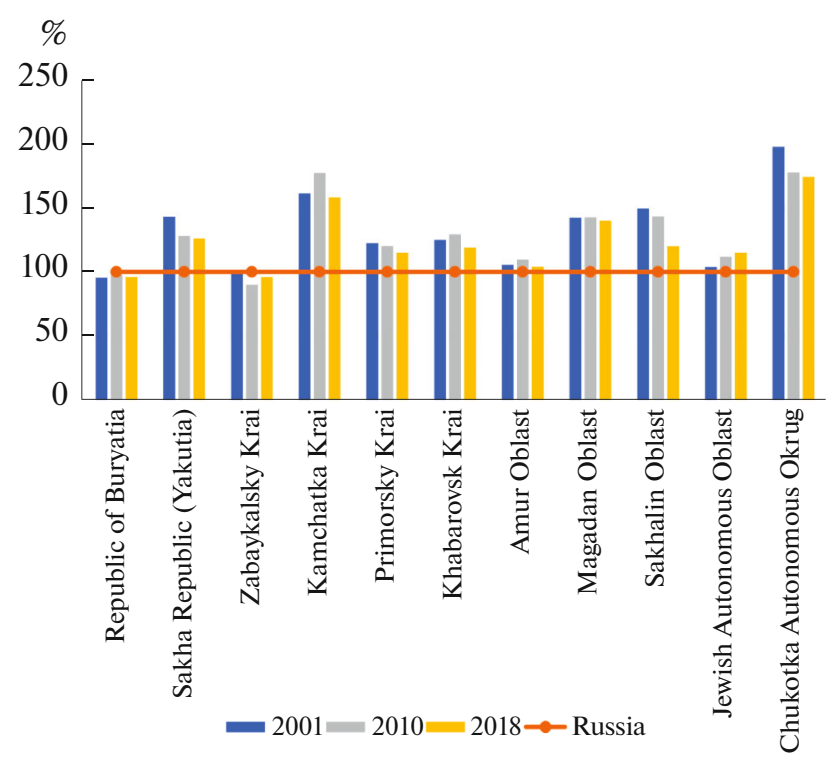

Fig. 4. Cost of fixed set of consumer goods and services $($ Russia $=100 \%)$. the Far East, it is $10.5 \%$. The amount of reimbursement by the population for costs associated with housing and communal services to housing and communal services' companies in the FEFD is officially set at a much lower level, only $74.3 \%$ vs. $94.4 \%$ for Russia as a whole. However, significant price increases in the region mean that even with such a "preferential" regime, e.g., in Chukotka, $12.6 \%$ of all consumer spending is household spending on utility bills.

As a result, the purchasing power of household income is very low, exceeding the average Russian level in 2019 only in three regions: Sakhalin Oblast, the Chukotka Autonomous Okrug, and Magadan Oblast (the deviation in them was, respectively, $+0.62,+0.45$, and +0.06 units to the Russian Federation indicator) due to the higher wages formed in the natural resource sector of the economy of these territories.

It is the rapid growth of wages in the singleresource economies of the Far Eastern region that ensured the statistically observed improvement in purchasing power of average per capita incomes compared to 1995, when no Far Eastern subject showed an excess of pensions in relation to the average Russian indicator. The rapid growth in the ratio of wages and cost of living in Sakhalin Oblast, the Sakha Republic (Yakutia), Magadan Oblast, and the Chukotka Autonomous Okrug improved the statistical pattern in 2019 compared to 1995. Otherwise, this pattern would have been even worse even from a purely statistical viewpoint due to progressive "retirement poverty" (Table 4).

It is unsurprising that in the Far East, on average, the poverty level for more than 20 years has remained higher than in Russia as a whole, although the number of various programs and projects, including various 
Table 4. Ratio of income and minimum cost of living in federal subjects of the FEFD and in Russia as a whole

\begin{tabular}{l|c|c|c|c|c|c}
\hline \multirow{2}{*}{\multicolumn{1}{c|}{ Federal subject }} & \multicolumn{6}{c}{ Ratio to cost of living } \\
\cline { 2 - 7 } & \multicolumn{7}{|c|}{ average monthly wages } & average monthly accrued pensions & \multicolumn{2}{c}{ average per capita money income } \\
\cline { 2 - 7 } & 1995 & 2019 & 1995 & 2019 & 1995 & 2019 \\
\hline Republic of Buryatia & 1.64 & 3.43 & 0.76 & 1.28 & 1.23 & 2.20 \\
Sakha Republic (Yakutia) & 1.97 & 4.22 & 0.71 & 1.15 & 1.63 & 2.65 \\
Zabaykalsky Krai & 1.18 & 3.56 & 0.55 & 1.18 & 1.02 & 2.09 \\
Kamchatka Krai & 2.32 & 3.86 & 0.69 & 1.09 & 1.83 & 2.55 \\
Primorsky Krai & 1.80 & 3.51 & 0.75 & 1.16 & 1.50 & 2.78 \\
Khabarovsk Krai & 1.78 & 3.51 & 0.78 & 1.23 & 1.42 & 2.88 \\
Amur Oblast & 1.99 & 3.89 & 0.82 & 1.28 & 1.66 & 2.70 \\
Magadan Oblast & 1.94 & 4.73 & 0.64 & 1.18 & 1.79 & 3.29 \\
Sakhalin Oblast & 1.78 & 5.84 & 0.72 & 1.36 & 1.41 & 3.85 \\
Jewish Autonomous Oblast & 1.46 & 2.98 & 0.76 & 1.08 & 1.22 & 1.84 \\
Chukotka Autonomous Okrug & 2.45 & 4.81 & 0.55 & 1.13 & 1.65 & 3.68 \\
FEFD & $\mathbf{1 . 9 8}$ & $\mathbf{4 . 0 2}$ & $\mathbf{0 . 7 6}$ & $\mathbf{1 . 2 1}$ & $\mathbf{1 . 4 5}$ & $\mathbf{2 . 6 9}$ \\
Russia & $\mathbf{1 . 7 9}$ & $\mathbf{4 . 3 5}$ & $\mathbf{0 . 9 2}$ & $\mathbf{1 . 3 8}$ & $\mathbf{1 . 9 5}$ & $\mathbf{3 . 2 3}$ \\
\hline
\end{tabular}

benefits for the population, has grown during this time, especially after 2015. The share of people with money incomes below the subsistence minimum after the active contraction period (2000-2012), the seventh year remains higher than the national average: $15.7 \%$ in the Far East vs. $12.6 \%$ in Russia as a whole (Fig. 5). Only in four Far Eastern federal subjects (the Chukotka Autonomous Okrug, Magadan and Sakhalin oblasts, Khabarovsk Krai) in 2018 was the share of the population with incomes below the subsistence level in the total population lower than in the country as a whole. This is, of course, better than in 2005 , when the Chukotka Autonomous Okrug was the only such subject; however, for the bulk of the region's population, the share of people living below the poverty line is still higher than in Russia as a whole. Of course, this cannot generate positive motivation either for potential migrants or for those who decide to leave the region or stay in it.

Of course, the living wage indicator itself is very odious, with a very big stretch capable of characterizing the real standards of the minimum household budget in specific territories, especially in very heterogeneous conditions for the functioning of markets, access to them, the level of competition in local markets, etc. To some extent, it is possible to obtain an idea of the extend of such heterogeneity for individual territories in the Far East from data on the regional settlement pattern. Although the population is mainly concentrated in cities and large settlements, every third inhabitant of the Far East lives in a hard-toreach, significantly remote local settlement, for which there are seasonal restrictions on the timing, scale, form of delivery of goods and an objectively narrow list of available goods and services.

The minimum cost of living reflects such a contradiction to the real picture that this indicator confuses the real income situation more than it clarifies it. The literature notes at least four specific functions performed by this indicator: (1) a cost assessment of the material situation of needy residents of regions for the formation of an assistance and support policy for citizens in a particular region; (2) justification of financial assistance to regions for implementation of relevant authority; (3) a rating indicator reflecting, in the eyes of the federal center, the effectiveness of the activities of regional authorities; (4) an indicator of the effec-

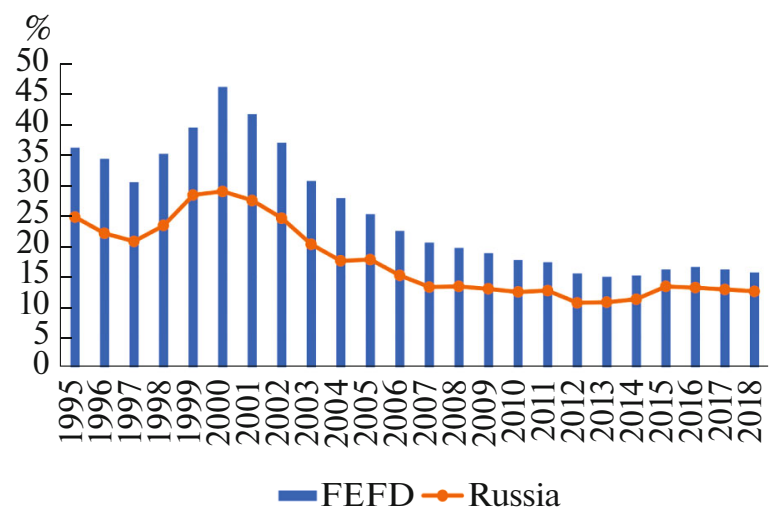

Fig. 5. Share of population with incomes below subsistence level, $\%$ of total population. 


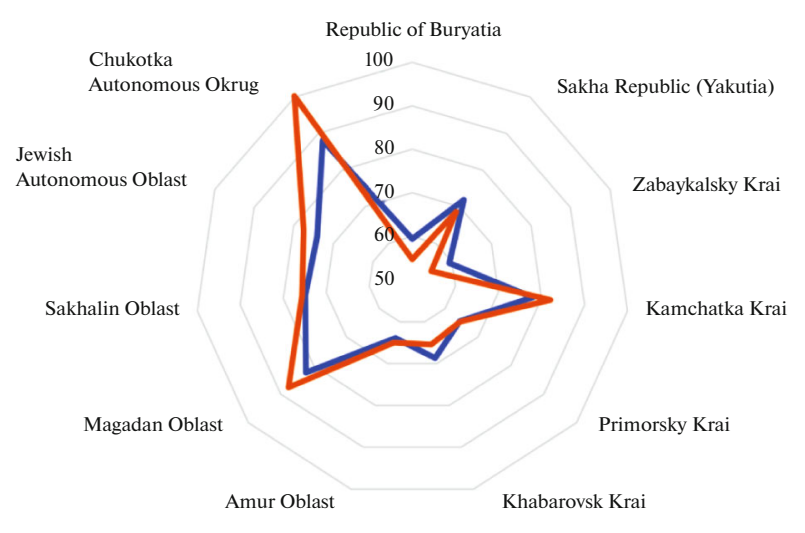

Coverage of children with preschool education, $\%$ of children aged $1-6$ years Availability of spots for preschool children in preschools, spots per 100 children

Fig. 6. Availability of preschool for children.

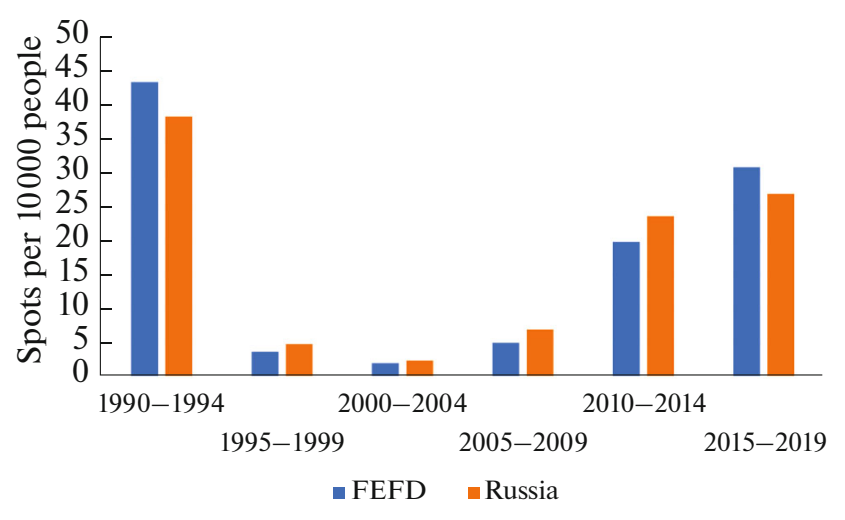

Fig. 7. Commissioning of preschools, spots per 10000 people.

tiveness of the ongoing social and economic policy. ${ }^{9}$ It should also be added that the value of the subsistence minimum in each specific region is very closely related (and this relationship is negative) with the capabilities of the local budget. It is unsurprising that in federal subjects, including the regions of the FEFD, suffering from chronic deficits, the value of the subsistence level is increasingly being manipulated by authorities seeking to ensure their administrative efficiency. ${ }^{10}$

\section{QUALITY OF LIFE}

The existing household income level plays an extremely important role in shaping the long-term

\footnotetext{
${ }^{9}$ Gontmakher E. Outdated innovations: why the Constitution does not need a living wage // RBC. 2020. Jan 30. https://www. rbc.ru/opinions/economics/30/01/2020/5e3144a89a7947297b $31 \mathrm{c} 5 \mathrm{c} 4$

${ }^{10}$ How the cost of living became political // Vedomosti. 2020. Jan 29. https://www.vedomosti.ru/opinion/articles/2020/01/ 29/821781- prozhitochnii-minimum.
}

motivation of the population. An equally important role-perhaps even more important for some cohorts of the population-is quality of life and long-term comfort. This is determined by the components of the formation and growth of the value of human capital in the scale and quality characteristics of the social infrastructure, which ensures functioning of education, health care, culture and sports, and housing and social policies-in other words, a highly developed and comfortable living environment.

After 1992, saturation with elements of social infrastructure in the Far East began to rapidly decrease due to dominant commercial criteria for the development and functioning of the network of these elements. The number of kindergartens and nurseries has decreased two to three times, and in the northern territories, four to five times. This was due not only to population decrease as a result of the migration outflow, but also to the active policy of "ridding" departments of incidental activities and related facilities on the balance sheets of industrial enterprises, as well as lack of funds from local budgets for maintenance of preschools. The averaged statistics give a very distorted picture of the real state of affairs.

Thus, in terms of the availability of preschools, the Far East as a whole almost reaches the average Russian level $(66.3 \%$ of children attend kindergartens and nurseries vs. $67.2 \%$ on average in the country). However, this is underlain by extraordinary differentiation of spatially distributed demand (Fig. 6), due to the extremely uneven distribution of the population over vast areas of the region. Only $30 \%$ of the population lives in the northern zone of the region and its density is 0.4 people per $\mathrm{km}^{2}$, and in the south, with $70 \%$ of the population, the density reaches 3 people per $\mathrm{km}^{2}$. Accordingly, even a fairly ruined system of social facilities in the northern zone with an ever rapidly decreasing population, turns out to be significantly more numerous than in the populated south, which determines the main potential for economic development. Whereas in the Chukotka Autonomous Okrug, Kamchatka Krai, the Sakha Republic (Yakutia), and Sakhalin and Magadan oblasts, the proportion of children aged 1-6 years attending preschools ranges from 72 to $88 \%$; in the southern zone of the Far East and Transbaikalia, there are about $40-45 \%$ fewer places for children.

At the same time, the outrunning construction of preschool institutions in the Far Eastern region, which by inertia continued until 1995, fell sharply; in the next 15 years (1995-2009), it was almost completely supported only by the Sakha Republic (Yakutia), where $60 \%$ of all new facilities were commissioned. Only in 2010 did this process recover under the influence of active state demographic policy; however, only after 2015, the Far East began to catch up to the federal parameters due to the advantage of the pace of construction (Fig. 7). 
If the issues of maintaining preschool children can be solved by various options, including the market for private services, then general education assumes that children of the corresponding age have complete access to state (municipal) educational institutions. The population outflow in the 1990s objectively led to a decrease in the number of school-age children, which motivated ideologists of national projects to close schools and optimize the entire system of primary and secondary education in order to increase the efficiency of the educational process. By 2015, when the absolute minimum number of students was recorded, the contingent of schoolchildren in regions of the northern zone of the Far East amounted to only $25-30 \%$ of the 1990 level; in regions of the southern zone, $40 \%$; in Transbaikalia, $50 \%$. During the same period, the number of educational institutions decreased by $25 \%$. For the Far East and Transbaikalia, this turned into a catastrophe, since schools in small settlements and remote areas, where transport accessibility is limited not only by the lack of high-quality roads, but also by weather conditions, primarily fell victim to contraction.

Despite the altered trend, due to the increase in the birth rate, towards natural replenishment of the contingent of schoolchildren, contraction of number of schools continues. For 2015-2019, the number of educational organizations decreased by another $7.8 \%$, while the number of students, on the contrary, increased by $12 \%$, and in the future its growth will only continue. Judging from the fact that the introduction of new schools in the Far East is not only slowing down per 10000 people compared to the national average, in 2015-2019, for the first time since 1995, it became less than in the Russian Federation, in absolute terms (24200 places vs. 34800 in the Russian Federation); Far Eastern students and their parents will have to put up with worse educational conditions for a long time, in particular, $18 \%$ of students in the FEFD as a whole (vs. $12.8 \%$ on average in Russia) are forced to study on the second and third shifts (Fig. 8).

The main indicators for provision of medical services in the Far Eastern region are traditionally better than the national average, since the existing settlement system makes it necessary to maintain an extensive network of medical institutions in remote cities and towns. Nevertheless, the possibilities of inpatient treatment for the population of the Far East and Transbaikalia have decreased throughout the reform years, largely facilitated by implementation of projects to optimize and modernize the national health care system. Whereas in 1990 there were 148 hospital beds for every 10000 people in the entire macroregion (on average for Russia this is 137 beds), by 2018 this figure decreased by $34 \%$ to 97 beds (on average for Russia, 80 beds). There is a significant gap in the allocation of beds and medical personnel. Almost all northeastern subjects of the FEFD maintain a high level of hospital beds, but most qualified medical personnel are con-

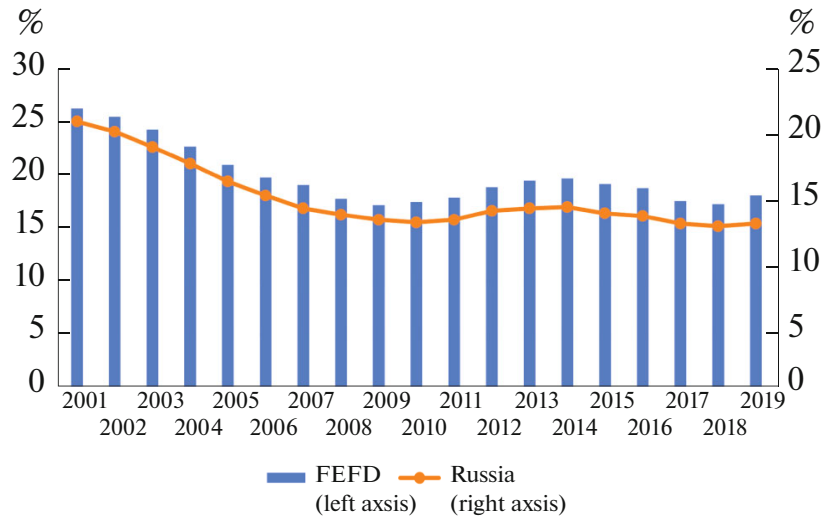

Fig. 8. Proportion of schoolchildren studying on second and third shifts, $\%$ of total students.

centrated in the southern zone of the macroregion, which host the main federal and regional medical centers.

However, the most serious problem is the contradiction between availability of medical infrastructure, in which the Far East retains its leading position among other federal districts, on the one hand, and the lowest health indicators of the population, on the other. Hospital beds are regularly commissioned in the region, and in relation to the population, they are introduced significantly more frequently than the average for the Russian Federation. This gap has been growing with particular intensity since 2015, when, there were 28000 beds per 100000 people (for 20152019) vs. 14000 in the Russian Federation. ${ }^{11}$ Life expectancy in the subjects of the macroregion lags by 2-3 years behind the average Russian indicator, and in some territories, the situation is even worse. In Chukotka, the gap reaches 9.3 years; in the Jewish Autonomous Oblast and Zabaykalsky Krai, 4.0-4.3 years. Infant and working-age mortality rates exceed the national average.

Official reports about the growth in availability of medical services are clearly discordant with the chronic shortage of resources (human, material, technical, and financial), which generates a high level of social exclusion, actually cutting off residents of rural and remote northern regions of the FEFD from affordable and high-quality medical care (D'yachenko V. and D'yachenko S., 2018). Continuous health care reforms lead to reallocation of medical personnel and medical institutions themselves in favor of relatively large and developed populated areas. For residents of small settlements, this becomes, if not a catastrophe, then a powerful factor that reduces the quality of life.

\footnotetext{
${ }^{11}$ Regions of Russia: Socioeconomic indicators: Stat. Dig., Moscow: Rosstat, 2000-2019; Socioeconomic situation in Russia. 2019: Analytical report, Moscow: Rosstat, 2019. https://gks.ru/bgd/regl/b19_01/Main.htm.
} 


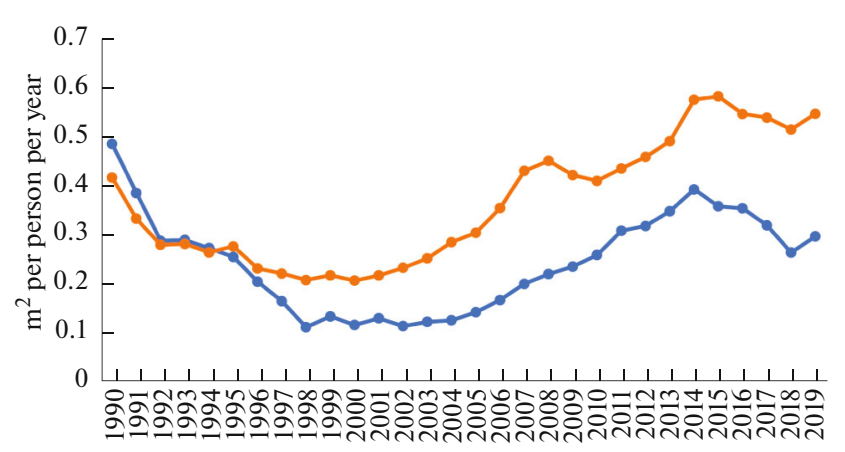

$\rightarrow$ FEFD $\rightarrow$ Russia

Fig. 9. Housing commissioning, $\mathrm{m}^{2}$ per person per year.

During the 2000s, the statistical indicators for provision of people in the Far East with medical care improved, and most of the territories began to be included in the top twenty for this indicator. However, this was and is being achieved mainly via reduction in the size of the local population. The improvement in statistics in no way affected the availability of medical services. Expansion of the list of paid services and the low household income level, especially during periods of disability, significantly limited the possibilities of preventing morbidity and restoring the health of Far Easterners (Gritsko and Polivaeva, 2017). At the same time, social stratification within the regions, which is not taken into account by official statistics, continues: availability of medical services is increasing in large and central populated areas due to degradation of small and unpromising settlements (Gritsko and Kolbina, 2013).

The situation is no better for housing conditions, which is an extremely sensitive demographic factor for Russia. This often plays a decisive role in the formation of the motivational intentions of potential migrants, but it is also very important for the motivational attitudes in the resident population, both in terms of migration and family planning. In this sphere, the situation is similar to that already discussed for education and medicine. According to the statistics, everything is much better than in reality. After 1990, as a result of population outflow from northern and eastern federal subjects, the average provision of their populations with living space significantly increased compared to the average Russian level (in Magadan and Sakhalin oblasts, the Chukotka Autonomous Okrug, and Kamchatka Krai). However, in the region as a whole, the level of housing provision in 2018 was only $95 \%$ of the national average, having increased compared to 1990 (85\%) mainly due to a decrease in population: when people left the region, they could not take their square meterage with them. ${ }^{12}$ Commis-

\footnotetext{
${ }^{12}$ The total area of living quarters per person on average. https://fedstat.ru/indicator/40466.
}

sioning of new housing in the region progressively lags behind the average Russian indicators (Fig. 9).

Commissioning of new housing at a level of $1 \mathrm{~m}^{2}$ per person per year, which is necessary for normal reproduction and renovation of the housing stock, remains an unattainable dream in the post-Soviet period. In recent years, only Primorsky Krai and the Sakha Republic (Yakutia) have demonstrated commissioning of about $0.6 \mathrm{~m}^{2}$ per person per year. However, there is also the problem of housing quality and affordability. Low rates of construction, and, consequently, renovations lead to an increase in housing area requiring major repairs and restoration. The already low quality of housing, which is still provided with $75 \%$ of communal services, is deteriorating, which of course corresponds to the average Russian level, but cannot be an attractive motif for the population.

Reformers' efforts to facilitate access to housing in the Far East by introducing preferential mortgages for some categories of residents only formally seem like a promising and large-scale institutional innovation. In fact, if we measure the affordability of housing by the possibility of purchasing it with a mortgage, the situation without any subsidies does not seem entirely hopeless. According to the RIA Rating Agency, in 2019, many federal subjects in the Far East have a high share of families that can afford a mortgage. ${ }^{13}$ However, like any generalized information, this says little about the real state of affairs. At least two circumstances should be taken into account: first, the market value of housing, and second, the household income in specific territories. In the Primorsky Krai, based on the rating, only $20 \%$ of families can afford a mortgage for a two-room apartment. Vladivostok is the most expensive city in terms of housing prices. And in Magadan Oblast, almost $65 \%$ of families have the opportunity to buy an apartment on a mortgage, not so much because of high incomes, but because of low demand for housing and low housing market prices. Considering these data, it should be understood that the main factor in housing affordability is its level of demand. And the latter is determined by the demographic dynamics in specific regions.

An important factor that oppresses income in the Far East associated with the housing market is its high maintenance costs. It was mentioned above that a preferential rate of the share of payments in the total cost of housing maintenance was applied to the Far East. However, payment for a standard apartment exceeds the average Russian level by about 1.52 times.

\footnotetext{
${ }^{13}$ Rating of regions in terms of affordability for families to buy housing on a mortgage. https://riarating.ru/infografika/ 20200311/630157302.html.
} 


\section{CONCLUSIONS}

After 30 years of reforms aimed at "improving the level and quality of life of the population in the country," and after a series of efforts to "create comfortable living conditions in the Far East," the factors hindering these processes remain unchanged, in any case, in the opinion of the population itself. Among the factors limiting the development of human capital in the Far East, residents of the macroregion themselves cite the following:

-limited choice of places for qualified work;

-low wages;

-lack of comfortable housing or high prices for it;

-low level of accessibility and quality of social services (housing and communal services, education, healthcare, culture);

- isolation from the central part of the country due to high transport costs on national and regional routes.

Is this a consequence of poor governance based on defects in management ideas and/or inability to implement them, the result of institutional failure, or rather, the collapse of the institutional paradigm of managing the functioning and development of large socioeconomic systems?

An appeal to the logic of historical development, a detailed analysis of which goes far beyond the scope of this article, but which has been analyzed in sufficient detail in a number of scientific publications (Minakir 2006, 2010; Rossiiskii...2017; etc.), gives grounds to state the following.

(1) The general idea of settling the region and creating and maintaining the potential for social and demographic development through the formation of massive incentives for the population was successfully realized when the system of direct state patronage was functioning; i.e., incentives were created and funded by the state itself for all feed-forward and feedback. That is, we can say that the idea or ideas of forming a sociodemographic environment by creating a system of positive incentives for the population are completely rational in and of themselves, if only because there is empirical evidence of this.

(2) These ideas cannot be realized or their implementation will be unconvincing if the instruments of direct government regulation and financing are replaced (as is happening at the present time) by indirect (institutional) signals that can only work if economic and managerial agents are unconditionally subordinate to them. There is no direct transformation of these signals through intermediate agents of sociodemographic systems.

Therefore, the authors' position is that the answer to the question posed the title of this article is as follows: failures in stabilizing the demographic potential and developing the social system in the Far East are associated with the wrong emphasis of state policy in this area on "institutional regulation." That is, the cause of failures is not institutional failure, but failure of the institutional paradigm of achieving the policy goal.

\section{FUNDING}

The study was supported by the Russian Foundation for Basic Research (project no. 20-010-00818 A).

\section{CONFLICT OF INTEREST}

The authors declare they have no conflict of interest.

\section{REFERENCES}

Aganbegyan, A.G., Development of the Far East: a national program in the context of national projects, Prostranstvennaya Ekon., 2019, vol. 15, no. 3, pp. 165-187. https://doi.org/10.14530/se.2019.3.165-181

D'yachenko, V.G. and D'yachenko, S.V., Health protection of the population of the Russian Far East in the context of the liberal transformation of the economy and social relations, Vestn. Obshch. Zdorov. Zdravookhr. Dal'nego Vost. Ross., 2018, no. 3 (32). http://www.fesmu.ru/voz/20183/2018301.aspx. Accessed April 6, 2020.

Gritsko, M.A. and Kolbina, E.O., Spatial deformations of performance of health care system, Prostranstvennaya Ekon., 2013, no. 4, pp. 107-121. https://doi.org/10.14530/se.2013.4.107-121

Gritsko, M.A. and Polivaeva, O.G., The general trends and results of the commercialization of the social sphere (by the example of healthcare), Vlast' Upr. Vost. Ross., 2017, no. $3(80)$, pp. 54-62.

https://doi.org/10.22394/1818-4049-2017-80-3-54-62

Minakir, P.A., Ekonomika regionov. Dal'nii Vostok (Regional Economic: Far East), Moscow: Ekonomika, 2006.

Minakir, P.A., Regional'naya ekonomicheskaya dinamika: Dal'nii Vostok (Regional Economic Dynamics of the Far East), Khabarovsk: Dal'nevost. Otd., Ross. Akad. Nauk, 2010.

Minakir, P.A., Issledovanie ekonomiki Dal'nego Vostoka, 1975-2000 (Economic Research of the Far East, 1975-2000), Khabarovsk: Inst. Ekon. Issled., Dal'nevost. Otd., Ross. Akad. Nauk, 2017a.

Minakir, P.A., Expectations and realities of the "turn to the East” policy, Ekon. Reg., 2017b, vol. 13, no. 4, p. 1025. https://doi.org/10.17059/2017-4-4

Motrich, E.L., Demographic development of the Khabarovsk Krai: problems and prospects, Narodonaselenie, 2019, vol. 22, no. 3, pp. 30-46. https://doi.org/10.24411/1561-7785-2019-00025

Motrich, E.L. and Molodkovets, L.A., Development of population and labor resources of the Russian Far East, Ekon. Sots. Peremeny: Fakty, Tendentsii, Prognoz, 2019, vol. 12 , no. 1, pp. 53-69.

https://doi.org/10.15838/esc.2019.1.61.3 
Motrich, E.L. and Naiden, S.N., Population and social development of the Russian Far East, Prostranstvennaya Ekon., 2009, no. 2, pp. 47-67.

Rossiiskii Dal'nii Vostok na puti v budushchee (Russian Far East towards Future), Minakir, P.A., Ed., Khabarovsk: Inst. Ekon. Issled., Dal'nevost. Otd., Ross. Akad. Nauk, 2017.

Rybakovsky, L.L. and Kozhevnikova, N.I., Eastern vector of demographic development in Russia, Narodonaselenie, 2015, no. 1, pp. 4-16.
Tikhookeanskaya Rossiya-2030: stsenarnoe prognozirovanie regional'nogo razvitiya (Pacific Russia-2030: Strategic Forecasting of Regional Development), Minakir, P.A., Ed., Khabarovsk: Dal'nevost. Otd., Ross. Akad. Nauk, 2010.

Tikhookeanskaya Rossiya-2050: sintez nauchno-tekhnicheskikh i ekonomicheskikh prognozov (Pacific Russia2030: Synthesis of Scientific-Technical and Economic Forecasts), Minakir, P.A. and Sergienko, V.I., Eds., Vladivostok: Dal'nauka, 2011. 